\title{
Systems Dynamic Approach in Development of Infrastructure in Entikong, Border Regions Indonesia - Malaysia
}

\author{
Ilyas Tommy ${ }^{1}$, Dianariana Dwi ${ }^{2}$, Suryani Fitri ${ }^{2, a}$ and Henni ${ }^{3}$ \\ ${ }^{1}$ Department of Civil Engineering, Faculty of Engineering, University of Indonesia, Depok 16424, Indonesia \\ ${ }^{2}$ Department of Civil Engineering, Faculty of Engineering, University of Persada Indonesia, Jakarta, Indonesia \\ ${ }^{3}$ Department of Industrial Engineering, Engineering Faculty, University of Persada Indonesia, Jakarta, Indonesia
}

\begin{abstract}
National strategic area needs to be supported by the various sectors in order to spur growth in the surrounding areas so that the surrounding region can develop and reduced. Public works infrastructure that includes roads, infrastructure for housing, infrastructure, water resources, and energy becomes one of the important components in the economic development efforts of the region as well as the reduction of disparities between regions. Entikong, as a national strategic areas, border areas designated as a national strategic area that needs to be supported by the physical infrastructure of the structure-forming region in order to achieve existence to support the functioning of the economy, social and defense.
\end{abstract}

\section{Introduction}

Kalimantan border area has a very strategic location, because it is located in the midst of the territory of Southeast Asian countries, and is flanked by two international shipping lanes, the South China Sea and the Celebes Sea / Sulu. The strategic role of Kalimantan border area apart as a security belt, is also the gateway and the image of the nation. Moreover, with large forest resources within the scope of the global environment, this area is a buffer zone and the lungs of the world.

Kalimantan border area, is currently the border area whose interaction with the large neighboring countries, both in terms of trade, labor and cross social relationships and kinship. The strategic position held Kalimantan border area has not been well explored for public welfare and national income for his role as a security belt is very prominent which are necessary at that time. This resulted in the border area of Indonesia neglected and regarded as an area that should be kept secure. With the condition, remote and limited facilities and infrastructure while dealing with residential area which have good infrastructure and human resource capacity is high, then there is an unequal socioeconomic relations. This condition, if left unchecked, will cause adverse effects, particularly the image of Indonesia is getting worse in the international world.

Entikong is a district in West Kalimantan Province, Indonesia. Entikong has a land border with a country lane Malaysia, especially Sarawak so that the landline is often referred to as the Silk Road can pass directly by bus both from Indonesia and Malaysia

Based on data from Sanggau Planning and Regional Development Agency (BAPPEDA), livelihood Entikong districts by GDP per capita in 2011 Rp. 9,396,432.92 / year contribution of the

\footnotetext{
${ }^{\text {a }}$ Corresponding author : suryani.fitri21@yahoo.com
} 
agricultural sector Rp. 46,009,480,000.00 is comprised of farmers 5,567 people (36\%), traders 382 people $(2.5 \%)$, has not been or is not working 3,465 people $(23 \%)$. Entikong has a total population in 2013 is 15.056 people (men: 7682 inhabitants, women: 7374 inhabitants), a density of 30 inhabitants / $\mathrm{km} 2$, regional per capita income of Rp. 8,604,313.37 / year.

Frontier in the Sanggau district along $\pm 129.50 \mathrm{Km}(15 \%)$ of the length of the border line of \pm 966 $\mathrm{Km}$ West Kalimantan. Sanggau district strategic position is: in the middle of West Kalimantan Province, adjacent land with Sarawak (East Malaysia), located on the Trans Kalimantan Strip, located on the Trans Borneo Trails, located on track Kapuas River, and accessibility: $\pm 90 \mathrm{Km}$ (2 hours) from / to Kuching, Sarawak, $\pm 119 \mathrm{Km}$ from / to Pontianak, located in the Kapuas river as in Figure 1.



Figure 1. Strategic position of Sanggau District.

\section{System and Dynamic Model Development Public Private Partnership in the Development of border Regions Indonesia-Malaysia}

Dynamic system is a methodology to study the issues around who saw the problem an overall (holistic). This methodology is not like another methodology that examines the problems with the sort them into parts of smaller and mutually limiting. Primary concept of dynamic system is understanding of how all the objects in a system interacting with one another. Dynamic system according to the community dynamic system is a methodology to learn and managing complex feedback systems, such as those are commonly encountered in the business world and other social systems.

Based on the results of the first year of the study showed that there are four infrastructure sectors that need attention are: Transportation, Housing, Energy / Electricity and Water. The development of a dynamic system models of Public Private partnership in the border region Indonesia - Malaysia development based on infrastructure networking in the area Entikong Sanggau West Kalimantan was conducted in four infrastructure sectors, namely transport infrastructure, settlements infrastructure, energy infrastructure and water infrastructure, development models aim to get percentage of financing infrastructure development scheme for the Government and private sector $[1,2]$ such as public private partnerships scheme for funding infrastructure [3,4]. The causal relationship diagram of the four infrastructure are as follows: 
a) Transport infrastructure - sub-system of transport infrastructure is built to model the structure of relationships that make up the causal relationship between the various variables and parameters in the sub-system of transport infrastructure. A variety of variables and parameters as well as the causal structure of sub-systems that make up the transportation infrastructure. can be seen in the diagram the structure of a causal relationship (causal loop diagram / CLD) in Figure 2 below:

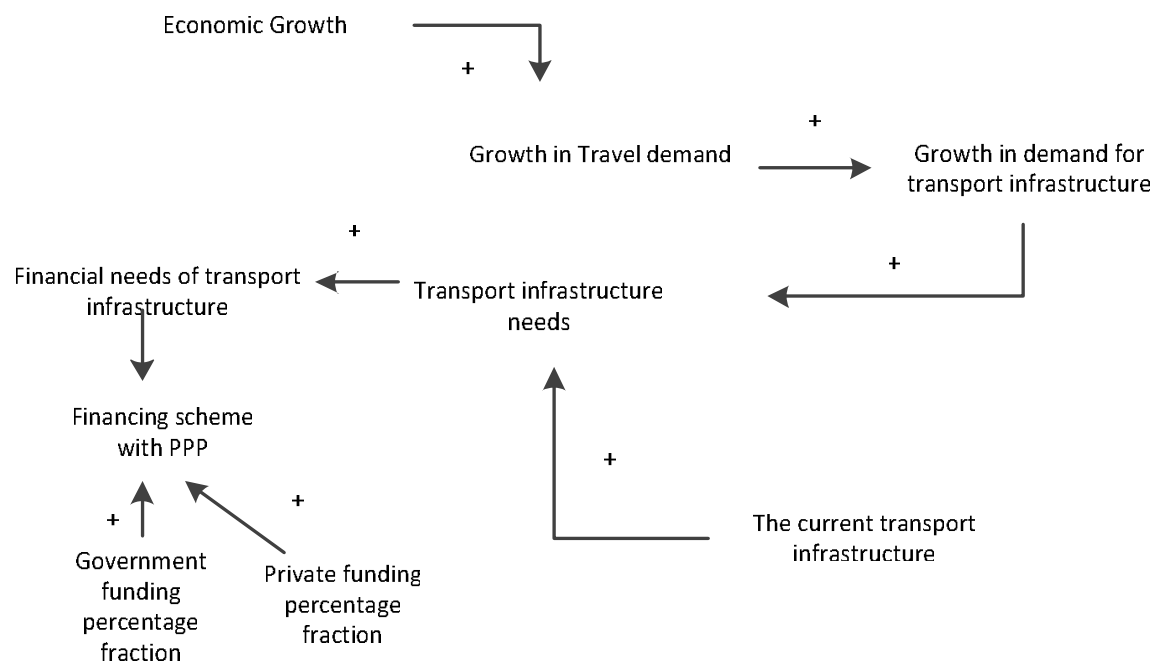

Figure 2. Causal loop diagram structure transportation infrastructure.

b) Settlements infrastructure - on sub system will illustrate the need for citizens Sanggau Settlements. Sub Settlements system infrastructure is built to model the structure of relationships that make up the causal relationship between the various variables and parameters in the subsystem of the settlements infrastructure. A variety of variables and parameters as well as the causal structure of sub-systems that make up the infrastructure of the Settlements can be seen in the diagram the structure of a causal relationship (causal loop diagram / CLD) in Figure 3.

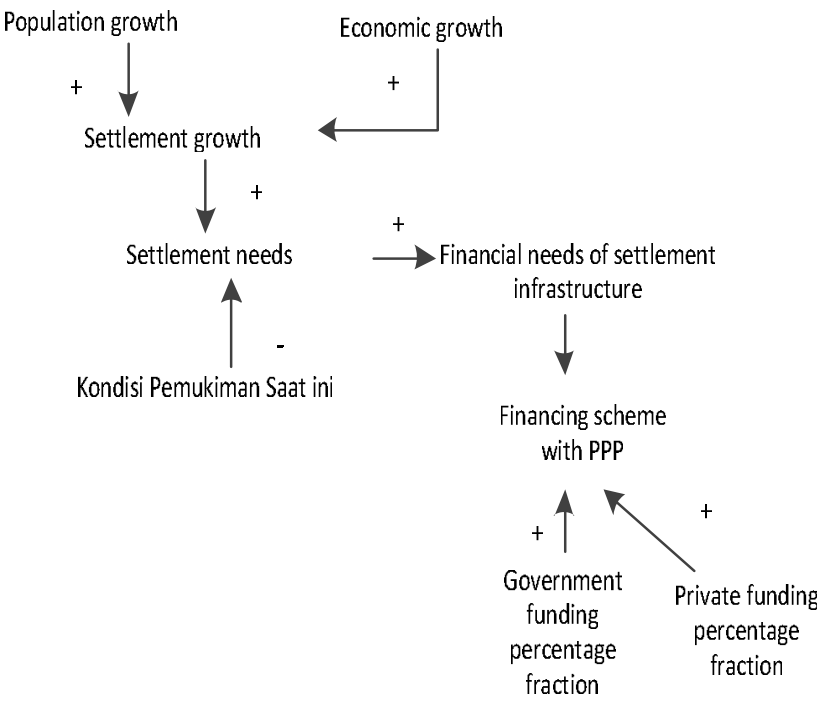

Figure 3. Causal loop diagram structure settlements infrastructure. 
c) Energy/ electricity infrastructure - causal structure that forms the sub system intrastruktur energy/ electricity can be seen in the diagram causal relationship between the various variables and parameters in the sub-system energy infrastructure / electricity. A variety of variables and parameters as well as the causal structure of sub-systems that make up the infrastructure of energy/ electricity can be seen in the diagram the structure of a causal relationship (causal loop diagram/ CLD) in Figure 4.

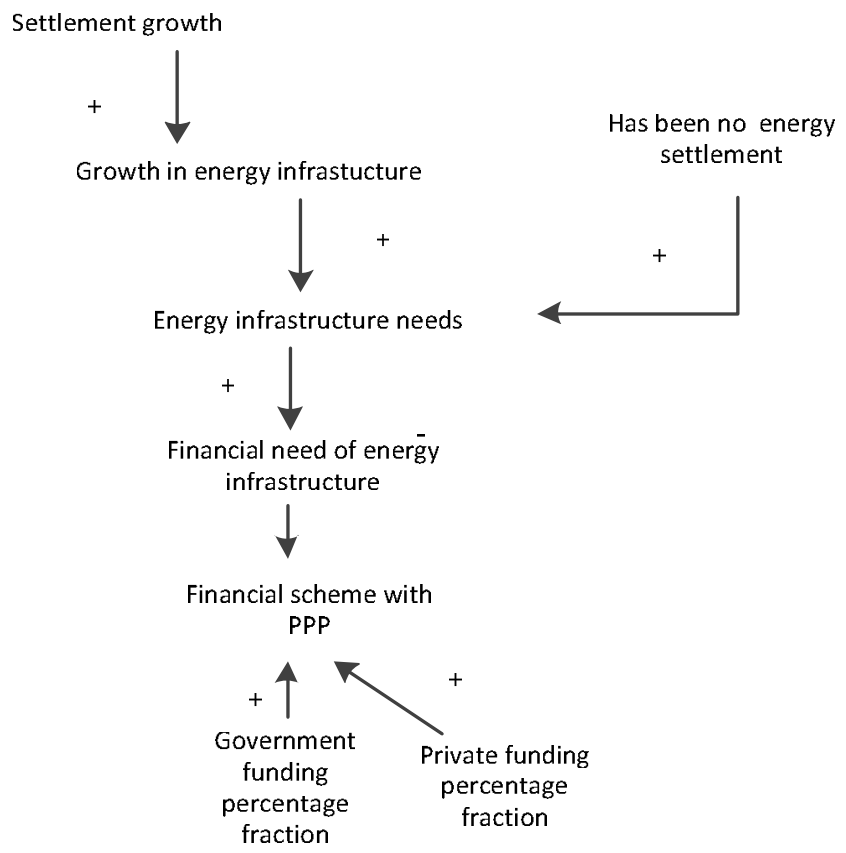

Figure 4. Causal loop diagram structure energi/ electricity infrastructure.

d) Clean water infrastructure - causal structure that forms the sub system intrastruktur clean water can be seen in the diagram causal relationship between the various variables and parameters in the sub-system of clean water infrastructure. A variety of variables and parameters as well as the causal structure of sub-systems that make up the clean water infrastructure can be seen in the diagram the structure of a causal relationship (causal loop diagram / CLD) in Figure 5.

Border regions needs to be addressed, because as the country face of entrance gate and then the border areas should be developed primarily related to Network of 4 its main infrastructure: Settlements, transportation, energy and water.

\section{Conclusions}

There are four infrastructure sectors that need attention are: Transportation, Housing, Energy / Electricity and Water. The development of a dynamic system models of Public Private partnership in the border region Indonesia - Malaysia development based on infrastructure networking in the area Entikong Sanggau West Kalimantan was conducted in four infrastructure sectors, namely transport infrastructure, Settlements Infrastructure, Energy Infrastructure and Water Infrastructure. Development in the border regions require approaches welfare and the environment, in addition to the security approach. For the example is constructions of a parallel road borders and development of plantations along the border line. The construction of a parallel road has a dual function, namely enhance border security and open borders inland isolation. Local economic development needs to be more emphasis on the spatial dimension. Regions need to combine sectoral cluster-based approach in 
which current business / sectors in the regions and the poor tend to cluster. There needs to be integration with the rural development strategies of urban development strategies. The village is generally still lagging behind in various types of infrastructure. This integration is expected to be developed rural-urban linkage and intercity networks (network Cities).



Figure 5. Causal loop diagram structure clean water infrastructure.

\section{Acknowledgements}

The main financial support from the Directorate General of Higher Education, Ministry of Technology Research and Higher Education Republic of Indonesia by National Strategic Grants 2015 is gratefully acknowledged.

\section{References}

[1] Bappenas, Indonesia Infrastructure Development, Ministry of National Development, Planning Agency of Indonesia, Jakarta, (2012).

[2] E. Heurkens, Changing Public Private Partnerships Roles in Urban Area Development in the Netherlands, Delft University of Technology, (2009).

[3] E.R. Yescombe, Public Private Partnerships Principles of Policy and Finance, Elsevier, (2007).

[4] R. Alasad, M. Ibrahim and O. Stephen, A system dynamics-based model for demand forecasting in PP infrastructure project - a case of toll road, Organization, Technology and Management in Construction International Journal, 5, 791-798, (2013). 